\section{CardioRenal Medicine}

\title{
Possible Inhibitory Effect of Erythropoiesis-Stimulating Agents at the Predialysis Stage on Early-Phase Coronary Events after Hemodialysis Initiation
}

\author{
Masato Nishimura ${ }^{a}$ Keitaro Watanabe ${ }^{b}$ Yuki Kitamurac \\ ${\text { Takao Nagashimac }{ }^{c} \text { Toshiko Tokoro }^{b} \text { Toru Takatani }^{b} \text { Nodoka Sato }}^{c}$ \\ Satoru Yamazaki ${ }^{d}$ Tetsuya Hashimoto $^{c}$ Hiroyuki Kobayashic \\ Toshihiko Ono ${ }^{c}$ \\ ${ }^{a}$ Cardiovascular Division, ${ }^{b}$ Department of Nephrology, and ${ }^{c}$ Department of Urology, \\ Toujinkai Hospital, and d Department of Urology, Toujinkai Clinic, Kyoto, Japan
}

\section{Key Words}

Anemia Chronic kidney disease $\cdot$ Coronary plaque Erythropoiesis-stimulating agent . Hemodialysis

\begin{abstract}
Background: We examined whether the use of erythropoiesis-stimulating agents (ESAs) to correct anemia at the predialysis stage could inhibit early-phase coronary events after hemodialysis initiation. Methods: We enrolled 242 patients with chronic kidney disease who had received continued medical treatments and initiated maintenance hemodialysis from 1 September 2000 to 31 December 2014 at Toujinkai Hospital. Patients with a previous history of blood transfusion or any cardiovascular events or interventions were excluded. The coronary events were followed for 1 year after initiation of hemodialysis. Results: Coronary events occurred in 51 of 242 patients: 10 patients had acute coronary syndrome [9 with percutaneous coronary intervention (PCI), 1 without intervention], and 41 had elective coronary revascularization (38 PCI and 3 coronary artery bypass graft). ESA was administered in 118 of 242 patients (48.8\%). In stepwise logistic analysis, coronary events were positively associated with nonuse of ESA at the predialysis stage (odds ratio $2.66, p=0.005$ ) and diabetes mellitus (odds ratio $5.33, p<0.001$ ). When dividing the patients into 4 subgroups by blood hemoglobin $(\mathrm{Hb})$ level $(8.5 \mathrm{~g} / \mathrm{dl})$ and the use/ nonuse of ESA, coronary event-free survival rates were higher $(p=0.005)$ in those with $\mathrm{Hb} \geq 8.5$ $\mathrm{g} / \mathrm{dl}, \mathrm{ESA}+(86.6 \%, \mathrm{n}=82)$ and tended to be higher $(\mathrm{p}=0.055)$ in those with $\mathrm{Hb}<8.5 \mathrm{~g} / \mathrm{dl}, \mathrm{ESA}+$ $(86.1 \%, \mathrm{n}=36)$ than in patients with $\mathrm{Hb}<8.5 \mathrm{~g} / \mathrm{dl}$, ESA- $(68.6 \%, \mathrm{n}=86)$ in a Kaplan-Meier analysis. Conclusions: The use of ESA to correct anemia at the predialysis stage may inhibit earlyphase coronary events after hemodialysis initiation.




\section{CardioRenal Medicine}

Nishimura et al:: Possible Inhibitory Effect of Erythropoiesis-Stimulating Agents at the Predialysis Stage on Early-Phase Coronary Events after Hemodialysis Initiation

\section{Introduction}

Patients with end-stage renal disease undergoing maintenance dialysis have a 10- to 20 -fold greater incidence of cardiovascular death compared with the general population [1], which is mainly due to a high prevalence of coronary artery disease (CAD). Several studies noted that significant coronary stenosis was found in $50 \%$ or more of asymptomatic dialysis patients who underwent coronary angiography at early stages after the initiation of hemodialysis [2-4]. These findings indicate the progression of coronary atherosclerosis in the predialysis stages of chronic kidney disease (CKD) [5, 6]. In previous studies, almost one quarter of acute myocardial infarctions (MI) occurred within 1 year after hemodialysis initiation [7, 8]. In this study, we examined whether the use of erythropoiesis-stimulating agent (ESA) to correct renal anemia at the predialysis stage could affect early-phase coronary events after hemodialysis initiation.

\section{Subjects and Methods}

\section{Patients}

The flow diagram for the recruitment of subjects is shown in figure 1. Eligibility criteria included CKD patients who have had continued medical treatment through stages 4-5 for at least 6 months at Toujinkai Hospital and initiated hemodialysis at Toujinkai Hospital from 1 September 2000 to 31 December 2014. Exclusion criteria were as follows: (1) hemorrhagic lesions; (2) blood disorders; (3) malignancy; (4) history of red blood cell transfusion; (5) congestive heart failure of New York Heart Association grades III-IV; (6) moderate or worse valvular heart disease, and (7) any history of coronary revascularization such as coronary artery bypass graft (CABG) or percutaneous coronary intervention (PCI), or apparent CAD such as a history of acute MI. Of 265 patients who met the eligibility criteria, 23 patients were excluded based on the above criteria. Consequently, 242 patients ( $65.4 \pm 13.1$ years old, 155 men and 87 women) were enrolled in the study and followed for 1 year after starting dialysis.

\section{ESAs and Medications}

ESAs used at the predialysis stage were recombinant human erythropoietin (rHuEPO; epoetin beta) or long-acting ESAs (darbepoetin alpha or epoetin beta pegol). ESAs were administered in 118 of 242 patients (48.8\%) from at least 6 months before hemodialysis initiation. Epoetin beta was used in 74 patients $(3,000-$ $36,000$ units/month), epoetin beta pegol in 34 (25-100 $\mathrm{mg} / \mathrm{month})$, and darbepoetin alpha in 10 (30-120 $\mu \mathrm{g} /$ month). Oral iron preparation was administered before dialysis in 148 patients $(61.3 \%)$. Cardiovascular medications, including statins, were continued during the study period.

\section{Radionuclide Imaging}

Single-photon emission computed tomography (SPECT) using an iodinated fatty acid analogue, iodine$123-\beta$-methyl iodophenyl-pentadecanoic acid ( ${ }^{123}$ I-BMIPP), was performed on a midweek, non-dialysis day. The sensitivity, specificity, and accuracy of detecting CAD by BMIPP SPECT in hemodialysis patients was 96.1, 70.3, and 90.8\%, respectively [9]. The methods are described in detail elsewhere [9-11].

\section{Echocardiography}

The participants underwent echocardiography on a midweek non-dialysis day within 1 month after hemodialysis initiation, when the patients were in a state without apparent overfluid. Left ventricular ejection fraction was quantified using the biplanar Simpson's rule, and left ventricular mass was normalized to body surface area and is described herein as left ventricular mass index.

\section{Determination of Clinical Factors}

Values of blood pressure, cardiothoracic ratio, blood hemoglobin ( $\mathrm{Hb}$ ) concentration, and serum concentrations of creatinine, albumin, C-reactive protein, or ferritin were determined at 6 and 3 months (ferritin was determined at 3 months) before the initiation of hemodialysis. These values after the initiation of hemodialysis were measured before the dialysis session and determined at the point of hemodialysis initiation, 
CKD patients who had treatment at the predialyisis stage and initiated hemodialysis at Toujinkai hospital (1 September 2000 to 31 December 2014)

$$
\mathrm{n}=278
$$

Nishimura et al.: Possible Inhibitory Effect of Erythropoiesis-Stimulating Agents at the Predialysis Stage on Early-Phase Coronary Events after Hemodialysis Initiation

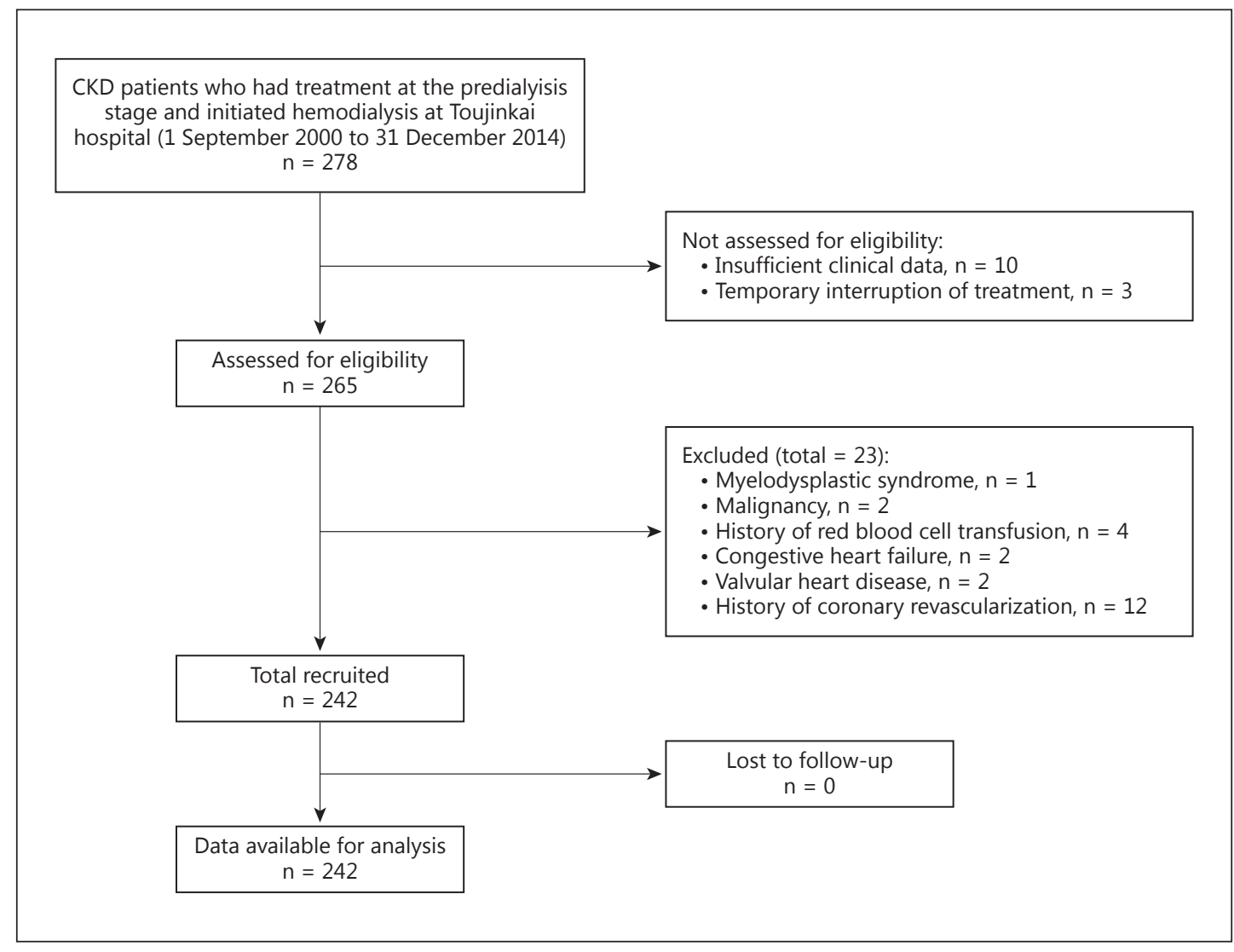

Fig. 1. Flow diagram for the recruitment of subjects.

and the mean values of the month were determined at 3, 6, 9, and 12 months after dialysis initiation. Blood samples ( $5 \mathrm{ml}$ ) were collected every 2 weeks before the first hemodialysis session of the week.

\section{End Point}

The end point was atherosclerotic coronary events, acute coronary syndrome such as unstable angina pectoris or acute MI, and obstructive CAD needing coronary revascularization.

\section{Statistical Analysis}

Values are expressed as the means \pm SD. The means of continuous variables were compared using nonpaired $t$ tests. Categorical data were analyzed using the $\chi^{2}$ test. The means of variables among the 4 subgroups were compared using one-way analysis of variance. The associations of clinical factors with coronary lesions were analyzed using logistic analysis. Stepwise logistic analysis was performed among significant $(\mathrm{p}<0.05)$ factors in univariate analysis. Coronary event-free survival rates were assessed using the Kaplan-Meier method and the log-rank test. p values $<0.05$ were considered significant. All statistical analyses were performed using IBM SPSS Statistics software, version 23.

\section{Results}

Of the 242 patients, 5 changed to other dialysis centers within 1 year after hemodialysis initiation; however, these 5 patients were included in the analysis, because we could confirm their coronary events and rate of survival. The other 237 patients were followed at Toujinkai Hospital to the end of this study. 
Nishimura et al.: Possible Inhibitory Effect of Erythropoiesis-Stimulating Agents at the Predialysis Stage on Early-Phase Coronary Events after Hemodialysis Initiation

Table 1. Differences in clinical data at the point of hemodialysis initiation between patients with or without coronary events

\begin{tabular}{lccc}
\hline & $\begin{array}{l}\text { Event+ } \\
(\mathrm{n}=51)\end{array}$ & $\begin{array}{c}\text { Event- } \\
(\mathrm{n}=191)\end{array}$ & p value \\
\hline Males, n (\%) & $38(74.5)$ & $117(61.3)$ & 0.080 \\
Age, years & $67.2 \pm 11.0$ & $65.0 \pm 13.5$ & 0.292 \\
Body mass index & $18.4 \pm 3.8$ & $19.3 \pm 4.1$ & 0.125 \\
Diabetes mellitus, n (\%) & $42(82.4)$ & $91(47.6)$ & $<0.001$ \\
Systolic blood pressure, mm Hg & $154.7 \pm 23.2$ & $154.9 \pm 26.2$ & 0.941 \\
Diastolic blood pressure, mm Hg & $78.8 \pm 14.8$ & $79.8 \pm 14.6$ & 0.666 \\
Cardiothoracic ratio, \% & $53.2 \pm 6.7$ & $52.1 \pm 5.7$ & 0.261 \\
Left ventricular ejection fraction, \% & $61.4 \pm 11.4$ & $61.9 \pm 12.8$ & 0.796 \\
Left ventricular mass index & $155.1 \pm 103.3$ & $145.6 \pm 51.4$ & 0.359 \\
Blood Hb, g/dl & $8.1 \pm 1.3$ & $8.6 \pm 1.4$ & 0.015 \\
Serum creatinine, mg/dl & $8.0 \pm 2.8$ & $8.9 \pm 3.3$ & 0.086 \\
Serum albumin, g/dl & $3.3 \pm 0.5$ & $3.4 \pm 0.5$ & 0.061 \\
Serum ferritin, ng/ml & $194.0 \pm 167.0$ & $182.6 \pm 260.6$ & 0.767 \\
Serum C-reactive protein, mg/dl & $0.250 \pm 0.148$ & $0.249 \pm 0.169$ & 0.987 \\
Use of ESAs, n (\%) & $16(31.4)$ & $102(53.4)$ & 0.005 \\
Medications, n (\%) & & & \\
$\quad$ Oral iron & $85(61.2)$ & $157(61.8)$ & 0.927 \\
Calcium channel blockers & $39(76.5)$ & $139(72.8)$ & 0.597 \\
$\quad$ RAS inhibitors & $22(43.1)$ & $115(60.2)$ & 0.169 \\
Alpha-1 blockers & $9(17.7)$ & $37(19.4)$ & 0.781 \\
Beta blockers & $13(25.5)$ & $37(19.4)$ & 0.340 \\
Antiplatelet drugs & $10(19.6)$ & $43(22.5)$ & 0.657 \\
Statins & $8(15.7)$ & $40(20.9)$ & 0.405 \\
\hline
\end{tabular}

\section{Coronary Events}

Coronary events were recognized in 51 of 242 patients (21\%) within 1 year after hemodialysis initiation. Acute coronary syndrome was observed in 10 patients: 7 acute MI and 3 unstable angina pectoris; 9 needed emergent PCI, and 1 patient was treated with tissue plasminogen activator. Elective coronary revascularization was performed in 41 patients (38 PCI and 3 CABG). Of these 41 patients, 16 had symptoms of effort angina; the other 25 patients were asymptomatic, but had significant changes in routine electrocardiography and abnormal findings in echocardiography and/or BMIPP SPECT. The coronary event group showed a higher rate of diabetes mellitus, a lower mean blood $\mathrm{Hb}$ concentration at hemodialysis initiation, and a lower use of ESAs at the predialysis stage than the non-event group (table 1).

\section{Factors Relevant to Coronary Events}

In univariate logistic analysis, coronary events were associated with diabetes mellitus, mean blood $\mathrm{Hb}$ concentration at hemodialysis initiation, and nonuse of ESAs (table 2). In stepwise logistic analysis of these factors, coronary events were associated with nonuse of ESA (odds ratio 2.66, 95\% CI 1.34-5.27; $\mathrm{p}=0.005$ ), independently of diabetes mellitus (odds ratio $5.33,95 \%$ CI 2.43-11.69; $\mathrm{p}<0.001$ ). The positive association of nonuse of ESAs with coronary events was consistently recognized in adjustment with mean blood Hb concentrations at hemodialysis initiation (odds ratio 2.04; $\mathrm{p}=0.048$ ), 3 months (odds ratio $2.40 ; \mathrm{p}=$ 0.013 ) and 6 months before dialysis (odds ratio 2.52; $\mathrm{p}=0.009$ ). When coronary events were limited to obstructive CAD needing coronary revascularization, coronary events were similarly associated with diabetes mellitus (odds ratio 5.00; $\mathrm{p}<0.001$ ), mean blood Hb concen- 
Nishimura et al.: Possible Inhibitory Effect of Erythropoiesis-Stimulating Agents at the Predialysis Stage on Early-Phase Coronary Events after Hemodialysis Initiation

Table 2. Univariate logistic analysis for coronary events

\begin{tabular}{|c|c|c|c|}
\hline & Odds ratio & $95 \% \mathrm{CI}$ & $\mathrm{p}$ value \\
\hline Male gender & 1.85 & $0.92-3.70$ & 0.083 \\
\hline Age (years) & 1.01 & $0.99-1.04$ & 0.291 \\
\hline Body mass index & 0.94 & $0.87-1.02$ & 0.126 \\
\hline Diabetes mellitus & 5.13 & $2.37-11.12$ & $<0.001$ \\
\hline Systolic blood pressure (mm Hg) & 1.00 & $0.99-1.01$ & 0.941 \\
\hline Diastolic blood pressure (mm Hg) & 0.99 & $0.97-1.02$ & 0.665 \\
\hline Cardiothoracic ratio $(\%)$ & 1.03 & $0.98-1.09$ & 0.260 \\
\hline Left ventricular ejection fraction (\%) & 1.00 & $0.97-1.02$ & 0.795 \\
\hline Left ventricular mass index & 1.00 & $1.00-1.01$ & 0.368 \\
\hline Blood $\mathrm{Hb}(\mathrm{g} / \mathrm{dl})$ & 0.75 & $0.59-0.95$ & 0.017 \\
\hline Serum creatinine (mg/dl) & 0.91 & $0.82-1.01$ & 0.087 \\
\hline Serum albumin (g/dl) & 0.56 & $0.30-1.03$ & 0.063 \\
\hline Serum ferritin (ng/ml) & 1.00 & $0.99-1.00$ & 0.766 \\
\hline Serum C-reactive protein $(\mathrm{mg} / \mathrm{dl})$ & 1.02 & $0.16-6.67$ & 0.987 \\
\hline Nonuse of ESA & 2.51 & $1.30-4.83$ & 0.006 \\
\hline \multicolumn{4}{|l|}{ Medications } \\
\hline Oral iron & 0.98 & $0.57-1.68$ & 0.926 \\
\hline Calcium channel blockers & 1.22 & $0.59-2.50$ & 0.595 \\
\hline RAS inhibitors & 0.61 & $0.33-1.14$ & 0.119 \\
\hline Alpha- 1 blockers & 0.89 & $0.40-1.99$ & 0.780 \\
\hline Beta blockers & 1.42 & $0.69-2.94$ & 0.339 \\
\hline Antiplatelet drugs & 0.84 & $0.39-1.81$ & 0.656 \\
\hline Statins & 0.70 & $0.31-1.61$ & 0.405 \\
\hline
\end{tabular}

tration at hemodialysis initiation (odds ratio 0.75; $\mathrm{p}=0.031$ ), and nonuse of ESAs (odds ratio $3.60 ; \mathrm{p}=0.001$ ). Further, we analyzed the data by dividing the entrée periods into $2000-$ 2008 and 2009-2014, because Japanese guidelines for treating renal anemia in the predialysis stage had been released in June 2008 [12]. In patients within the entrée period of 2000-2008, coronary events were associated with nonuse of ESAs (odds ratio 3.75; $\mathrm{p}=$ 0.047 ) and diabetes mellitus (odds ratio 7.21; $\mathrm{p}<0.001$ ), but not with blood Hb concentration at hemodialysis initiation (odds ratio $0.84 ; p=0.382$ ). The ratio of nonuse of ESAs was 0.68 , and the mean blood $\mathrm{Hb}$ concentration at hemodialysis initiation was $7.9 \pm 1.2 \mathrm{~g}$ / dl. In patients within the entrée period of 2009-2014, coronary events were associated with nonuse of ESAs (odds ratio 2.59; $\mathrm{p}=0.026$ ), blood $\mathrm{Hb}$ concentration at hemodialysis initiation (odds ratio 0.67; $\mathrm{p}=0.017$ ), and diabetes mellitus (odds ratio 4.451; $\mathrm{p}=0.009$ ). The ratio of nonuse of ESAs was 0.39 , and the mean blood Hb concentration at hemodialysis initiation was $8.8 \pm 1.4 \mathrm{~g} / \mathrm{dl}$. The use of renin-angiotensin system (RAS) inhibitors tended to be inversely associated with coronary events in patients within the entrée period of 20002008 (odds ratio 0.38; $p=0.083$ ), but not in those of within the period of 2009-2014 (odds ratio $0.78 ; \mathrm{p}=0.497$ ).

\section{Blood Hb and ESA Use/Nonuse}

When patients were divided into 4 subgroups by blood $\mathrm{Hb}$ level $(8.5 \mathrm{~g} / \mathrm{dl}$, the mean value for the study patients) and use/nonuse of ESAs, the incidences of coronary events were as follows: $\mathrm{Hb} \geq 8.5 \mathrm{~g} / \mathrm{dl}, \mathrm{ESA}+, 11 / 82$ (13.4\%); $\mathrm{Hb}<8.5 \mathrm{~g} / \mathrm{dl}, \mathrm{ESA}+, 5 / 36$ (13.9\%); $\mathrm{Hb} \geq 8.5 \mathrm{~g} / \mathrm{dl}$, ESA-, 8/38 (21.1\%), and $\mathrm{Hb}<8.5 \mathrm{~g} / \mathrm{dl}, \mathrm{ESA}-, 27 / 86$ (31.4\%). The incidence of coronary events was lower $(\mathrm{p}=0.042)$ in patients with $\mathrm{Hb} \geq 8.5 \mathrm{~g} / \mathrm{dl}$, ESA+ than in those with $\mathrm{Hb}<8.5 \mathrm{~g} / \mathrm{dl}$, ESA-. Coronary event-free survival rates at 1 year after starting hemodialysis were higher 


\section{CardioRenal Medicine}

\begin{tabular}{l|l}
\hline Cardiorenal Med 2017;7:21-30 \\
\hline DOI: 10.1159/000448009 & $\begin{array}{l}\text { (c) 2016 S. Karger AG, Basel } \\
\text { www.karger.com/crm }\end{array}$ \\
\hline
\end{tabular}

Nishimura et al.: Possible Inhibitory Effect of Erythropoiesis-Stimulating Agents at the Predialysis Stage on Early-Phase Coronary Events after Hemodialysis Initiation

Table 3. Differences in clinical data at hemodialysis initiation among the subgroups divided by blood $\mathrm{Hb}$ concentration and the use of ESAs

\begin{tabular}{|c|c|c|c|c|}
\hline & $\begin{array}{l}\mathrm{Hb} \geq 8.5 \mathrm{~g} / \mathrm{dl}, \\
\mathrm{ESA}+(\mathrm{n}=82)\end{array}$ & $\begin{array}{l}\mathrm{Hb}<8.5 \mathrm{~g} / \mathrm{dl}, \\
\mathrm{ESA}+(\mathrm{n}=36)\end{array}$ & $\begin{array}{l}\mathrm{Hb} \geq 8.5 \mathrm{~g} / \mathrm{dl}, \\
\mathrm{ESA}-(\mathrm{n}=38)\end{array}$ & $\begin{array}{l}\mathrm{Hb}<8.5 \mathrm{~g} / \mathrm{dl}, \\
\mathrm{ESA}-(\mathrm{n}=86)\end{array}$ \\
\hline Males, n (\%) & $52(63.4)$ & $23(63.9)$ & $28(73.7)$ & $52(60.5)$ \\
\hline Age, years & $64.2 \pm 14.4$ & $64.5 \pm 12.2$ & $63.7 \pm 15.0$ & $67.8 \pm 10.6$ \\
\hline Body mass index & $18.8 \pm 3.8$ & $19.1 \pm 3.6$ & $19.5 \pm 4.3$ & $19.2 \pm 4.4$ \\
\hline Diabetes mellitus, n (\%) & $47(57.3)$ & $17(47.2)$ & $21(55.3)$ & $48(55.8)$ \\
\hline Systolic blood pressure, mm Hg & $155.6 \pm 26.2$ & $149.4 \pm 23.4$ & $158.7 \pm 26.8$ & $154.9 \pm 25.2$ \\
\hline Diastolic blood pressure, $\mathrm{mm} \mathrm{Hg}$ & $82.4 \pm 15.7^{\mathrm{b}}$ & $76.9 \pm 12.9$ & $83.7 \pm 12.8$ & $76.2 \pm 14.1$ \\
\hline Cardiothoracic ratio, $\%$ & $52.4 \pm 6.4$ & $50.9 \pm 4.7$ & $51.3 \pm 6.2$ & $53.4 \pm 5.7$ \\
\hline Left ventricular ejection fraction, $\%$ & $62.2 \pm 13.6$ & $60.7 \pm 13.6$ & $61.0 \pm 12.5$ & $62.2 \pm 10.9$ \\
\hline Left ventricular mass index & $139.5 \pm 49.7$ & $140.3 \pm 58.3$ & $158.9 \pm 51.5$ & $153.2 \pm 84.6$ \\
\hline Blood Hb, g/dl & $9.8 \pm 0.9^{\mathrm{a}, \mathrm{c}, \mathrm{d}}$ & $7.5 \pm 0.7$ & $9.2 \pm 0.7^{\mathrm{a}, \mathrm{c}}$ & $7.3 \pm 0.8$ \\
\hline Serum creatinine, $\mathrm{mg} / \mathrm{dl}$ & $8.4 \pm 2.7$ & $9.6 \pm 3.7$ & $8.4 \pm 3.4$ & $8.8 \pm 3.3$ \\
\hline Serum albumin, $\mathrm{g} / \mathrm{dl}$ & $3.5 \pm 0.5^{b}$ & $3.4 \pm 0.5$ & $3.4 \pm 0.5$ & $3.3 \pm 0.5$ \\
\hline Serum ferritin, ng/ml & $52.3 \pm 6.4$ & $50.9 \pm 4.7$ & $51.3 \pm 6.2$ & $53.4 \pm 5.7$ \\
\hline Serum C-reactive protein, mg/dl & $0.245 \pm 0.157$ & $0.299 \pm 0.156$ & $0.242 \pm 0.187$ & $0.239 \pm 0.163$ \\
\hline $\begin{array}{l}\text { Meaications, } \mathrm{n}(\%) \\
\text { Oral iron }\end{array}$ & $52(63.4)$ & $25(69.4)$ & $25(65.8)$ & $47(54.7)$ \\
\hline Calcium channel blockers & $67(81.7)$ & $30(83.3)$ & $24(63.2)$ & $57(66.3)$ \\
\hline RAS inhibitors & $65(79.3)^{b}$ & $14(38.9)$ & $24(63.2)$ & $35(40.7)$ \\
\hline Alpha-1 blockers & $18(22.0)$ & $6(16.7)$ & $7(18.4)$ & $15(17.4)$ \\
\hline Beta blockers & $20(24.4)$ & $7(19.4)$ & $8(21.1)$ & $15(17.4)$ \\
\hline Antiplatelet drugs & $20(24.4)$ & 7 (19.4) & $10(26.3)$ & $16(18.6)$ \\
\hline Statins & $19(23.2)$ & $6(16.7)$ & $11(29.0)$ & $12(14.0)$ \\
\hline
\end{tabular}

${ }^{\mathrm{a}} \mathrm{p}<0.001$ versus $\mathrm{Hb}<8.5 \mathrm{~g} / \mathrm{dl}, \mathrm{ESA}-;{ }^{\mathrm{b}} \mathrm{p}<0.05$ versus $\mathrm{Hb}<8.5 \mathrm{~g} / \mathrm{dl}, \mathrm{ESA}-{ }^{\mathrm{c}}{ }^{\mathrm{p}}<0.001$ versus $\mathrm{Hb}<8.5 \mathrm{~g} / \mathrm{dl}, \mathrm{ESA}+;{ }^{\mathrm{d}} \mathrm{p}<0.05$ versus $\mathrm{Hb} \geq 8.5 \mathrm{~g} / \mathrm{dl}$, ESA-.

Fig. 2. Coronary event-free survival rates within 1 year after hemodialysis initiation among patients divided into 4 subgroups by blood $\mathrm{Hb}$ concentration at hemodialysis initiation $(8.5 \mathrm{~g} / \mathrm{dl})$ and use/nonuse of ESA in KaplanMeier analysis.

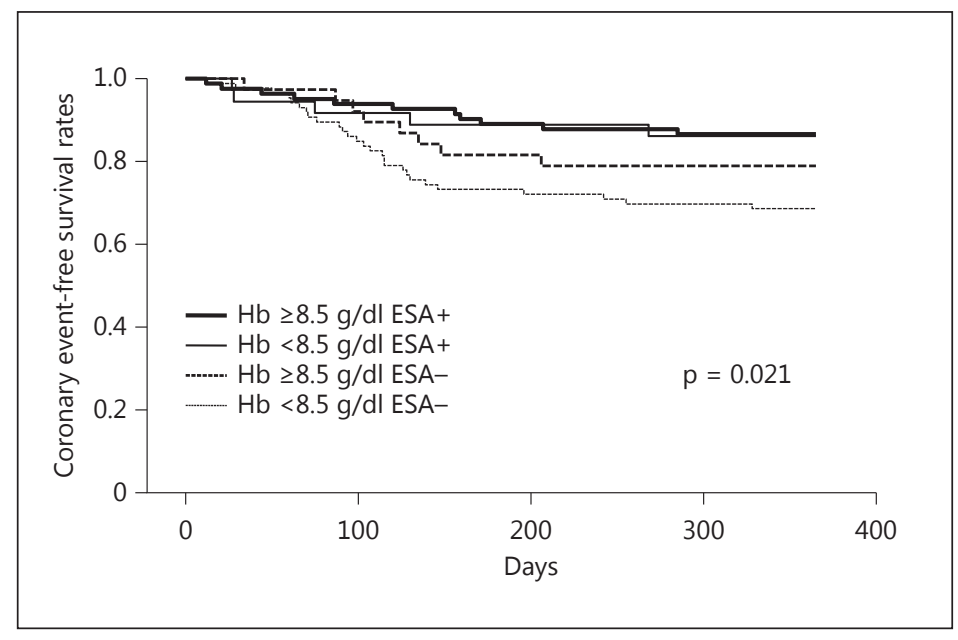

( $p=0.005)$ in patients with $\mathrm{Hb} \geq 8.5 \mathrm{~g} / \mathrm{dl}$, ESA+ and tended to be higher $(\mathrm{p}=0.055)$ in those with $\mathrm{Hb}<8.5 \mathrm{~g} / \mathrm{dl}, \mathrm{ESA}+$ than in patients with $\mathrm{Hb}<8.5 \mathrm{~g} / \mathrm{dl}$, ESA- in a Kaplan-Meier analysis (fig. 2). In patients with $\mathrm{Hb} \geq 8.5 \mathrm{~g} / \mathrm{dl}, \mathrm{ESA}+$, the mean blood $\mathrm{Hb}$ concentration at hemodialysis initiation was higher than in the other subgroups, and the mean serum albumin concentration and the administration rate of RAS inhibitors were higher than in patients with $\mathrm{Hb}<8.5 \mathrm{~g} / \mathrm{dl}$, ESA- (table 3). 


\section{CardioRenal Medicine}

\begin{tabular}{l|l}
\hline Cardiorenal Med 2017;7:21-30 \\
\hline DOI: 10.1159/000448009 & $\begin{array}{l}\text { @ 2016 S. Karger AG, Basel } \\
\text { www.karger.com/crm }\end{array}$ \\
\hline
\end{tabular}

Nishimura et al.: Possible Inhibitory Effect of Erythropoiesis-Stimulating Agents at the Predialysis Stage on Early-Phase Coronary Events after Hemodialysis Initiation

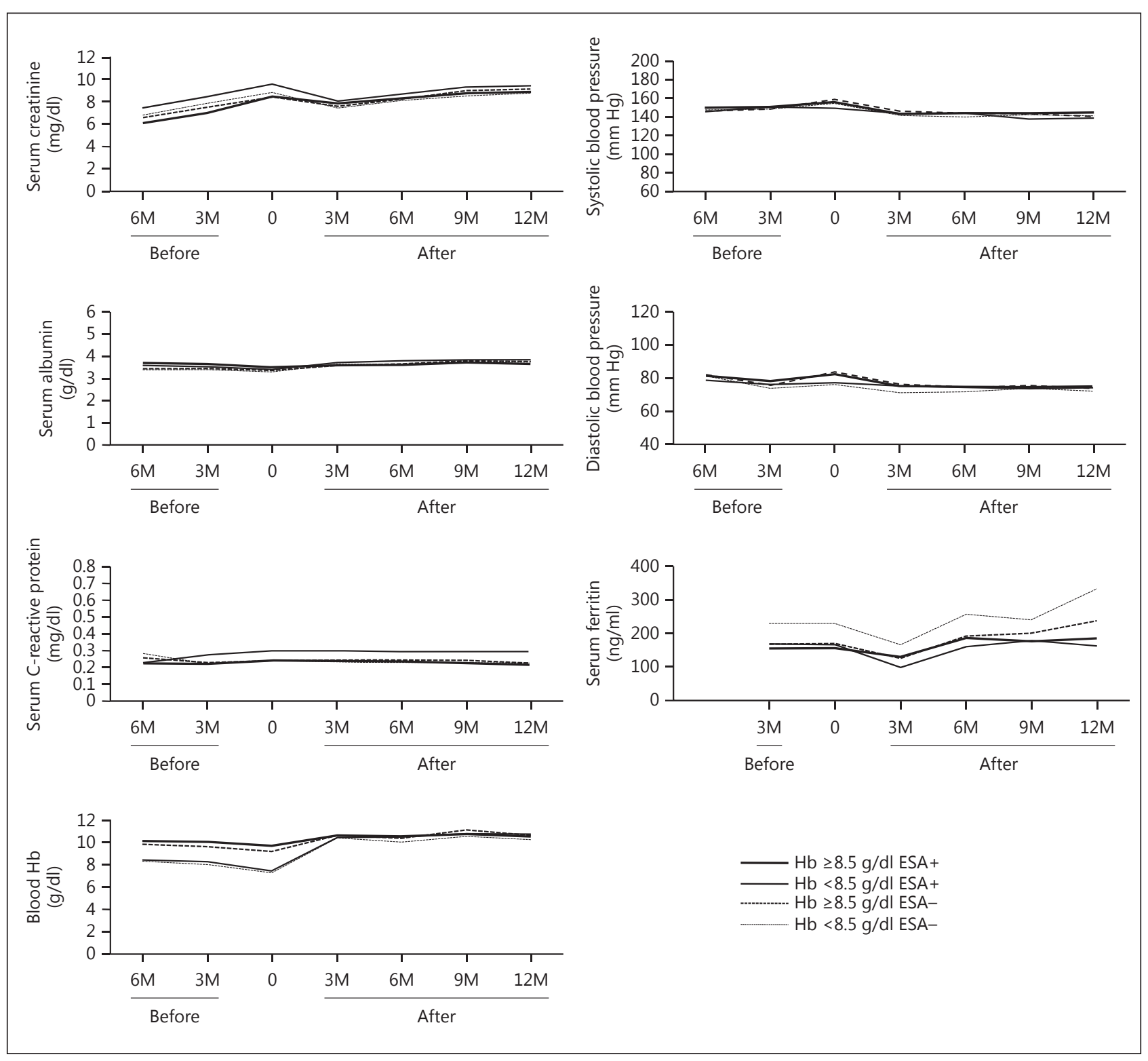

Fig. 3. Profiles of changes in blood pressure, blood $\mathrm{Hb}$, and serum concentrations of creatinine, albumin, Creactive protein, or ferritin during the study period among patients divided into 4 subgroups by blood $\mathrm{Hb}$ concentration at hemodialysis initiation $(8.5 \mathrm{~g} / \mathrm{dl})$ and use/nonuse of ESA. M = Months; Before = before hemodialysis initiation; After = after hemodialysis initiation; $0=$ hemodialysis initiation.

\section{Changes in Blood Hb and Other Factors}

The mean blood $\mathrm{Hb}$ concentrations of patients with $\mathrm{Hb} \geq 8.5 \mathrm{~g} / \mathrm{dl}$, ESA+ were higher than those of patients with $\mathrm{Hb}<8.5 \mathrm{~g} / \mathrm{dl}$, ESA + or $\mathrm{Hb}<8.5 \mathrm{~g} / \mathrm{dl}$, ESA- at 6 and 3 months before dialysis initiation (fig. 3, online suppl. data, www.karger.com/doi/10.1159/000448009) and higher than those of the other 3 subgroups at the initiation of hemodialysis (table 2). Mean serum albumin concentrations of patients with $\mathrm{Hb} \geq 8.5 \mathrm{~g} / \mathrm{dl}$, ESA+ were higher than those of patients with $\mathrm{Hb}<8.5 \mathrm{~g} / \mathrm{dl}, \mathrm{ESA}-$ at 6 and 3 months before dialysis initiation (fig. 3, online suppl. data) and at the initiation of hemodialysis (table 2). Mean values of other factors did not differ among the 4 subgroups during the study (fig. 3, online suppl. data). 
Nishimura et al.: Possible Inhibitory Effect of Erythropoiesis-Stimulating Agents at the Predialysis Stage on Early-Phase Coronary Events after Hemodialysis Initiation

\section{Types of ESAs and Coronary Events}

In the participants administered with ESAs at the predialysis stages $(n=118 ; 64.5 \pm 13.7$ years old; 75 men and 43 women), the rates of coronary events were lower $(p=0.027)$ in patients with long-acting ESAs $(2 / 44,4.6 \%)$ than in those with rHuEPO $(14 / 74,18.9 \%)$. In Kaplan-Meier analysis, coronary event-free survival rates at 1 year after starting hemodialysis were higher $(p=0.029)$ in patients with long-acting ESAs $(95.5 \%)$ than in those with rHuEPO (81.1\%).

\section{Discussion}

Coronary plaque is likely to progress with the stages of CKD. CKD patients of stage 3 had a higher percentage of lipid volume and a lower percentage of fibrous volume in coronary plaques compared with patients without CKD [5]. Recently, Kashiyama et al. [6] showed that coronary plaques progress with the CKD stages, and both lipid and fibrotic volumes of the plaques became greater as CKD advanced, particularly in stage 4 or 5. Coronary plaques are likely to progress as CKD worsens, and these morphological changes in coronary plaques are thought to lead to the occurrence of coronary events after hemodialysis initiation. To reduce early-phase coronary events after hemodialysis, it is important to inhibit the progression of coronary plaques at the predialysis CKD stages.

Iwasaki et al. [13] reported that the prevalence of CAD gradually declined from 69 to $25 \%$ over 18 years in hemodialysis patients, and the use of ESAs seemed to be associated with this decrease in CAD. Erythropoietin (Epo) and Epo receptor are expressed in a variety of tissues, including the vascular system [14]. Epo derivatives had antiapoptotic effects via inhibition of caspase 3 [15] and stabilization of the BAX/Bcl-2 ratio in apo E-deficient mice [16,17]. Epo diminished the production of inflammatory cytokines [18] and oxidative stress [19] and had beneficial effects on the morphology of atherosclerotic lesions of apo E knockout mice via reduction of the lipid content of macrophages and the subsequent formation of foam cells [20]. Darbepoetin alpha, a long-acting ESA, suppressed oxidative stress, inflammation in the heart and aorta, plaque stage, and plaque cholesterol content in subtotally nephrectomized rats [21]. The positive association of nonuse of ESA from the predialysis stage with obstructive CAD needing coronary revascularization found in this study would indicate the inhibitory effect of ESA on the progression of coronary plaque. ESA might play a role in inhibiting the process of coronary atherosclerosis in CKD patients, although further investigation is needed to clarify this important point.

Among the participants administered ESAs from the predialysis stage, long-acting ESAs led to a better prognosis in the occurrence of coronary events than rHuEPO. However, we cannot insist that long-acting ESAs are superior to rHuEPO in the inhibition of coronary events, because the administration of ESAs was not randomized, and these types of ESAs had been used at different times; rHuEPO was mainly used before 2012, and long-acting ESAs were used after 2012.

This study has several limitations. It was a retrospective, observational cohort study performed in a single center. Use or nonuse of ESA and types of ESAs were not randomized among the participants. A multicenter, randomized, and prospective trial would be needed to confirm the effects of the use of ESAs at the predialysis stage on coronary events. Many differences among the background factors may have affected the findings of this study, since the study period was very long, and rHuEPO and long-acting ESAs had been used at different times. The clinical factors presented in this study may not have been sufficient for proper conduction of the analysis; other factors that were not examined might have affected the results of this study. 
Nishimura et al.: Possible Inhibitory Effect of Erythropoiesis-Stimulating Agents at the Predialysis Stage on Early-Phase Coronary Events after Hemodialysis Initiation

The present study indicated the inhibitory effect of ESA at the predialysis stage on the early-phase coronary events after hemodialysis initiation, irrespective of the correction of anemia. Since the entrée duration was very long from 2000 to 2014, the clinical background including medication or medical care, such as the administration of ESAs or RAS inhibitors and target blood $\mathrm{Hb}$ levels for correction of renal anemia, has changed during this period. However, the positive association of nonuse of ESA with coronary events was similarly found in patients of the former (2000-2008) and latter (2009-2014) periods of this study. We have reported in previous studies the importance of detecting CAD in asymptomatic hemodialysis patients using myocardial scintigraphy such as fatty acid imaging $[9,10]$. The use of ESAs from the predialysis stage may play an important role in improving the prognosis of hemodialysis patients by inhibiting early-phase coronary events after hemodialysis initiation as well as improving renal anemia.

\section{Acknowledgments}

The authors deeply appreciate the staffs of the Kyoto Red Cross Hospital, Kyoto Medical Center, and Takeda General Hospital for coronary angiography, cardiac disease assessment, and coronary intervention.

\section{Statement of Ethics}

The Ethics Committee for Human Research of Toujinkai Hospital approved this study. All patients provided informed consent to all procedures associated with the study prior to participation.

\section{Disclosure Statement}

The authors declare no conflicts of interest.

\section{References}

1 Foley RN, Parfrey PS, Sarnak MJ: Epidemiology of cardiovascular disease in chronic renal disease. J Am Soc Nephrol 1998;9(suppl 12):S16-S23.

2 Joki N, Hase H, Nakamura R, Yamaguchi T: Onset of coronary artery disease prior to initiation of haemodialysis in patients with end-stage renal disease. Nephrol Dial Transplant 1997;12:718-723.

3 Ohtake T, Kobayashi S, Moriya H, Negishi K, Okamoto K, Maesato K, Saito S: High prevalence of occult coronary artery stenosis in patients with chronic kidney disease at the initiation of renal replacement therapy: an angiographic examination. J Am Soc Nephrol 2005;70:1142-1148.

4 Charytan D, Kuntz RE, Mauri L, DeFilippi C: Distribution of coronary artery disease and relation to mortality in asymptomatic hemodialysis patients. Am J Kidney Dis 2007;49:409-416.

5 Miyagi M, Ishii H, Murakami R, Isobe S, Hayashi M, Amano T, Arai K, Yoshikawa D, Ohashi T, Uetani T, Yasuda Y, Matsuo S, Matsubara T, Murohara T: Impact of renal function on coronary plaque composition. Nephrol Dial Transplant 2010;25:175-181.

6 Kashiyama K, Sonoda S, Muraoka Y, Suzuki Y, Kamezaki F, Tsuda Y, Araki M, Tamura M, Takeuchi M, Abe H, Okazaki M, Fujino Y, Otsuji Y: Coronary plaque progression of non-culprit lesions after culprit percutaneous intervention in patients with moderate to advanced chronic kidney disease: intravascular ultrasound and integrated backscatter intravascular ultrasound study. Int J Cardiovasc Imaging 2015;31:935-945.

7 Herzog CA, Ma JZ, Collins AJ: Poor long-term survival after acute myocardial infarction among patients on longterm dialysis. N Engl J Med 1998;339:799-805.

8 Iseki K, Fukiyama K: Long-term prognosis and incidence of acute myocardial infarction in patients on chronic hemodialysis. Am J Kidney Dis 2000;36:820-825.

9 Nishimura M, Hashimoto T, Kobayashi H, Fukuda T, Okino K, Yamamoto N, Fujita H, Inoue Tsunehiko Nishimura $\mathrm{N}$, Ono T: Myocardial scintigraphy using a fatty acid analogue detects coronary artery disease in hemodialysis patients. Kidney Int 2004;66:811-819. 
Nishimura et al.: Possible Inhibitory Effect of Erythropoiesis-Stimulating Agents at the Predialysis Stage on Early-Phase Coronary Events after Hemodialysis Initiation

10 Nishimura M, Murase M, Hashimoto T, Kobayashi H, Yamazaki S, Imai R, Okino K, Fujita H, Inoue N, Takahashi $\mathrm{H}$, Ono T: Influence of diabetes mellitus on diagnostic potential of iodine-123-BMIPP imaging for coronary artery stenosis in hemodialysis patients. J Nephrol 2006;19:481-491.

11 Nishimura M, Tsukamoto K, Hasebe N, Tamaki N, Kikuchi K, Ono T: Prediction of cardiac death in hemodialysis patients by myocardial fatty acid imaging. J Am Coll Cardiol 2008;51:139-145.

12 Tsubakihara Y, Nishi S, Akiba T, Hirakata H, Iseki K, Kubota M, Kuriyama S, Komatsu Y, Suzuki M, Nakai S, Hattori M, Babazono T, Hiramatsu M, Yamamoto H, Bessho M, Akizawa T: 2008 Japanese Society for Dialysis Therapy: guidelines for renal anemia in chronic kidney disease. Ther Apher Dial 2010;14:240-275.

13 Iwasaki M, Joki N, Tanaka Y, Hayashi T, Kubo S, Asakawa T, Matsukane A, Takahashi Y, Hirahata K, Imamura Y, Hase H: Declining prevalence of coronary artery disease in incident dialysis patients over the past two decades. J Atheroscler Thromb 2014;21:593-604.

14 Chong ZZ, Kang JQ, Maiese K: Angiogenesis and plasticity: role of erythropoietin in vascular systems. J Hematother Stem Cell Res 2002;11:863-871.

15 Cai Z, Manalo DJ, Wei G, Rodriguez ER, Fox-Talbot K, Lu H, Zweier JL, Semenza GL: Hearts from rodents exposed to intermittent hypoxia or erythropoietin are protected against ischemia-reperfusion injury. Circulation 2003;108:79-85.

16 Warren JS, Zhao Y, Yung R, Desai A: Recombinant human erythropoietin suppresses endothelial cell apoptosis and reduces the ratio of Bax to Bcl-2 proteins in the aortas of apolipoprotein E-deficient mice. J Cardiovasc Pharmacol 2011;57:424-433.

17 Katavetin P, Tungsana K, Eiam-Ong S, Nangaku M: Antioxidative effects of erythropoietin. Kidney Int 2007; 72:S10-S15.

18 Meng R, Zhu D, Bi Y, Yang D, Wang Y: Erythropoietin inhibits gluconeogenesis and inflammation in the liver and improves glucose intolerance in high-fat diet-fed mice. PLoS One 2013;8:e53557.

19 Chatterjee PK: Pleiotropic renal actions of erythropoietin. Lancet 2005;365:1890-1892.

20 Lu KY, Ching LC, Su KH, Yu YB, Kou YR, Hsiao SH, Huang YC, Chen CY, Cheng LC, Pan CC, Lee TS: Erythropoietin suppresses the formation of macrophage foam cells: role of liver X receptor alpha. Circulation 2010;121: 1828-1837.

21 Arend N, Hilgers KF, Campean V, Karpe B, Cordasic N, Klanke B, Amann K: Darbepoetin alpha reduces oxidative stress and chronic inflammation in atherosclerotic lesions of apo E deficient mice in experimental renal failure. PLoS One 2014;9:388601. 


\section{Erratum}

In the article by Nishimura $\mathrm{M}$ et al., entitled 'Possible inhibitory effect of erythropoiesis-stimulating agents at the predialysis stage on early-phase coronary events after hemodialysis initiation' [Cardiorenal Med 2017;7:21-30, DOI:10.1159/000448009], an error in the serum ferritin concentrations included in table 3 was identified after online publication of this paper in CardioRenal Medicine. This is a simple technical error and does not affect the point of any argument of this paper.

The corrected values of serum ferritin concentrations in table 3 are as follows: $\mathrm{Hb} \geq 8.5 \mathrm{~g} / \mathrm{dl}$, ESA+: $155.1 \pm 139.3 \mathrm{ng} / \mathrm{ml} ; \mathrm{Hb}<8.5 \mathrm{~g} / \mathrm{dl}, \mathrm{ESA}+: 165.5 \pm 132.3 \mathrm{ng} / \mathrm{ml} ; \mathrm{Hb} \geq 8.5 \mathrm{~g} / \mathrm{dl}, \mathrm{ESA}-: 168.2 \pm 220.1 \mathrm{ng} / \mathrm{ml} ; \mathrm{Hb}$ $<8.5 \mathrm{~g} / \mathrm{dl}, \mathrm{ESA}-: 229.1 \pm 344.1 \mathrm{ng} / \mathrm{ml}$.

Table 3. Differences in clinical data at hemodialysis initiation among the subgroups divided by blood Hb concentration and the use of ESAs

\begin{tabular}{|c|c|c|c|c|}
\hline & $\begin{array}{l}\mathrm{Hb} \geq 8.5 \mathrm{~g} / \mathrm{dl}, \\
\mathrm{ESA}+(\mathrm{n}=82)\end{array}$ & $\begin{array}{l}\mathrm{Hb}<8.5 \mathrm{~g} / \mathrm{dl}, \\
\mathrm{ESA}+(\mathrm{n}=36)\end{array}$ & $\begin{array}{l}\mathrm{Hb} \geq 8.5 \mathrm{~g} / \mathrm{dl}, \\
\mathrm{ESA}-(\mathrm{n}=38)\end{array}$ & $\begin{array}{l}\mathrm{Hb}<8.5 \mathrm{~g} / \mathrm{dl}, \\
\mathrm{ESA}-(\mathrm{n}=86)\end{array}$ \\
\hline Males, n (\%) & $52(63.4)$ & $23(63.9)$ & $28(73.7)$ & $52(60.5)$ \\
\hline Age, years & $64.2 \pm 14.4$ & $64.5 \pm 12.2$ & $63.7 \pm 15.0$ & $67.8 \pm 10.6$ \\
\hline Body mass index & $18.8 \pm 3.8$ & $19.1 \pm 3.6$ & $19.5 \pm 4.3$ & $19.2 \pm 4.4$ \\
\hline Diabetes mellitus, n (\%) & 47 (57.3) & $17(47.2)$ & $21(55.3)$ & $48(55.8)$ \\
\hline Systolic blood pressure, mm Hg & $155.6 \pm 26.2$ & $149.4 \pm 23.4$ & $158.7 \pm 26.8$ & $154.9 \pm 25.2$ \\
\hline Diastolic blood pressure, $\mathrm{mm} \mathrm{Hg}$ & $82.4 \pm 15.7^{\mathrm{b}}$ & $76.9 \pm 12.9$ & $83.7 \pm 12.8$ & $76.2 \pm 14.1$ \\
\hline Cardiothoracic ratio, $\%$ & $52.4 \pm 6.4$ & $50.9 \pm 4.7$ & $51.3 \pm 6.2$ & $53.4 \pm 5.7$ \\
\hline Left ventricular ejection fraction, $\%$ & $62.2 \pm 13.6$ & $60.7 \pm 13.6$ & $61.0 \pm 12.5$ & $62.2 \pm 10.9$ \\
\hline Left ventricular mass index & $139.5 \pm 49.7$ & $140.3 \pm 58.3$ & $158.9 \pm 51.5$ & $153.2 \pm 84.6$ \\
\hline Blood Hb, g/dl & $9.8 \pm 0.9^{\mathrm{a}, \mathrm{c}, \mathrm{d}}$ & $7.5 \pm 0.7$ & $9.2 \pm 0.7^{\mathrm{a}, \mathrm{c}}$ & $7.3 \pm 0.8$ \\
\hline Serum creatinine, mg/dl & $8.4 \pm 2.7$ & $9.6 \pm 3.7$ & $8.4 \pm 3.4$ & $8.8 \pm 3.3$ \\
\hline Serum albumin, g/dl & $3.5 \pm 0.5^{b}$ & $3.4 \pm 0.5$ & $3.4 \pm 0.5$ & $3.3 \pm 0.5$ \\
\hline Serum ferritin, $\mathrm{ng} / \mathrm{ml}$ & $155.1 \pm 139.3$ & $165.5 \pm 132.3$ & $168.2 \pm 220.1$ & $229.1 \pm 344.1$ \\
\hline Serum C-reactive protein, mg/dl & $0.245 \pm 0.157$ & $0.299 \pm 0.156$ & $0.242 \pm 0.187$ & $0.239 \pm 0.163$ \\
\hline \multicolumn{5}{|l|}{ Medications, n (\%) } \\
\hline Oral iron & $52(63.4)$ & $25(69.4)$ & $25(65.8)$ & 47 (54.7) \\
\hline Calcium channel blockers & $67(81.7)$ & $30(83.3)$ & $24(63.2)$ & $57(66.3)$ \\
\hline RAS inhibitors & $65(79.3)^{b}$ & $14(38.9)$ & $24(63.2)$ & $35(40.7)$ \\
\hline Alpha-1 blockers & $18(22.0)$ & $6(16.7)$ & $7(18.4)$ & $15(17.4)$ \\
\hline Beta blockers & $20(24.4)$ & $7(19.4)$ & $8(21.1)$ & $15(17.4)$ \\
\hline Antiplatelet drugs & $20(24.4)$ & $7(19.4)$ & $10(26.3)$ & $16(18.6)$ \\
\hline Statins & $19(23.2)$ & $6(16.7)$ & $11(29.0)$ & $12(14.0)$ \\
\hline
\end{tabular}

${ }^{\mathrm{a}} \mathrm{p}<0.001$ versus $\mathrm{Hb}<8.5 \mathrm{~g} / \mathrm{dl}, \mathrm{ESA}-;{ }^{\mathrm{b}} \mathrm{p}<0.05$ versus $\mathrm{Hb}<8.5 \mathrm{~g} / \mathrm{dl}, \mathrm{ESA}-{ }^{\mathrm{c}}{ }^{\mathrm{c}} \mathrm{p}<0.001$ versus $\mathrm{Hb}<8.5 \mathrm{~g} / \mathrm{dl}, \mathrm{ESA}+{ }^{\mathrm{d}} \mathrm{p}<0.05$ versus $\mathrm{Hb} \geq 8.5 \mathrm{~g} / \mathrm{dl}$, ESA-. 